\title{
Human T-Lymphotropic Viruses (HTLV)
}

\author{
Marina Lobato Martins, 1,3, Rafaela Gomes Andrade ${ }^{2,3}$, \\ Bernardo Hinkelmann Nédir ${ }^{2,3}$ and Edel Figueiredo Barbosa-Stancioli2,3 \\ ${ }^{1}$ Gerência de Desenvolvimento Técnico Científico, \\ Centro de Hematologia e Hemoterapia de Minas Gerais (Fundação HEMOMINAS), \\ ${ }^{2}$ Laboratório de Virologia Básica e Aplicada, \\ Departamento de Microbiologia, \\ Universidade Federal de Minas Gerais, \\ 3Interdisciplinary HTLV Research Group (GIPH) \\ Brazil
}

\section{Introduction}

\subsection{HTLV epidemiology}

The Human T-lymphotropic viruses (HTLV) belong to Retroviridae family, genus Deltaretrovirus. Currently they are classified into four types: 1, 2, 3 and 4 . The HTLV-1 was described in 1980 (Poiez et al., 1980) and since then has been identified on all five continents, with an estimated of 15 to 20 million infected people (Gessain, 1996). The areas are characterized as endemic, where the prevalence ranging from 0.5 to $20 \%$ in the population, depending on age and gender, or not endemic, where the prevalence is less than $0.1 \%$. The seroprevalence rates increase with age and are higher in females than males.

Areas of great prevalence for HTLV-1 include Japan, Sub-Saharan Africa, Caribbean basin, South America, Melanesia and the Middle East. The HTLV-2 was described in 1982 (Kalyanaraman et al., 1982) and it is endemic in African and Ameridian populations, but its worldwide distribution has been ascribed to transmission among intravenous drug users. HTLV-3 and 4 were discovered in a rural area of southern Cameroon (Mahieux \& Gessain, 2011; Wolfe et al., 2005) and, at present, they are restricted to that region.

HTLV-1 and 2 are transmitted sexually and vertically, firstly by breastfeeding, as well as parenterally, by contaminated blood transfusion, sharing of contaminated needles and syringes, or transplantation of infected organs and tissues. The level of HTLV-1 proviral load and anti-HTLV-1/2 antibodies are important to sexual or vertical virus transmission, besides the period of exposure to risk factors (sexual intercourse or breastfeeding). In endemic areas for HTLV-1, approximately $25 \%$ of infants breastfed by HTLV-1 seropositive mothers acquire the infection. Because of HTLV-1/2 transmission by blood transfusion, different countries have introduced at different times screening for the viruses in blood banks, some of them across the country and others only in endemic areas. The efficiency of HTLV-1 transmission by blood transfusion may depends of type and time stock of the blood component, besides the proviral load of the blood donor, since the 
transmission is dependent of the presence of infected cells. Lookback studies have shown different rates of seroconversion in patients who have received HTLV-1 infected blood, which is higher in areas with high prevalence than those with low prevalence (NamenLopes et al., 2009; Sullivan et al., 1991). Thus, HTLV-1/2 screening of blood units is important to prevents the most cases of transfusion transmitted infection, but the relatively long HTLV immunological window period (51 days) may lead to its transmission (Manns et al., 1992), been necessary stablish haemovigilance actions in blood banks.

\section{HTLV-1 genome}

HTLV has a particle of 110 to $140 \mathrm{~nm}$ in diameter with a lipoprotein envelope presenting surface and transmembrane proteins, important in the diagnosis of infection. Inside the capsid is found the viral genome, constituted by two copies of single-stranded RNA, besides viral proteins, such as reverse transcriptase and integrase, essential in the process of transcription of viral RNA into complementary DNA and integration of proviral DNA in the host cell genome (Cann \& Chen, 1996).

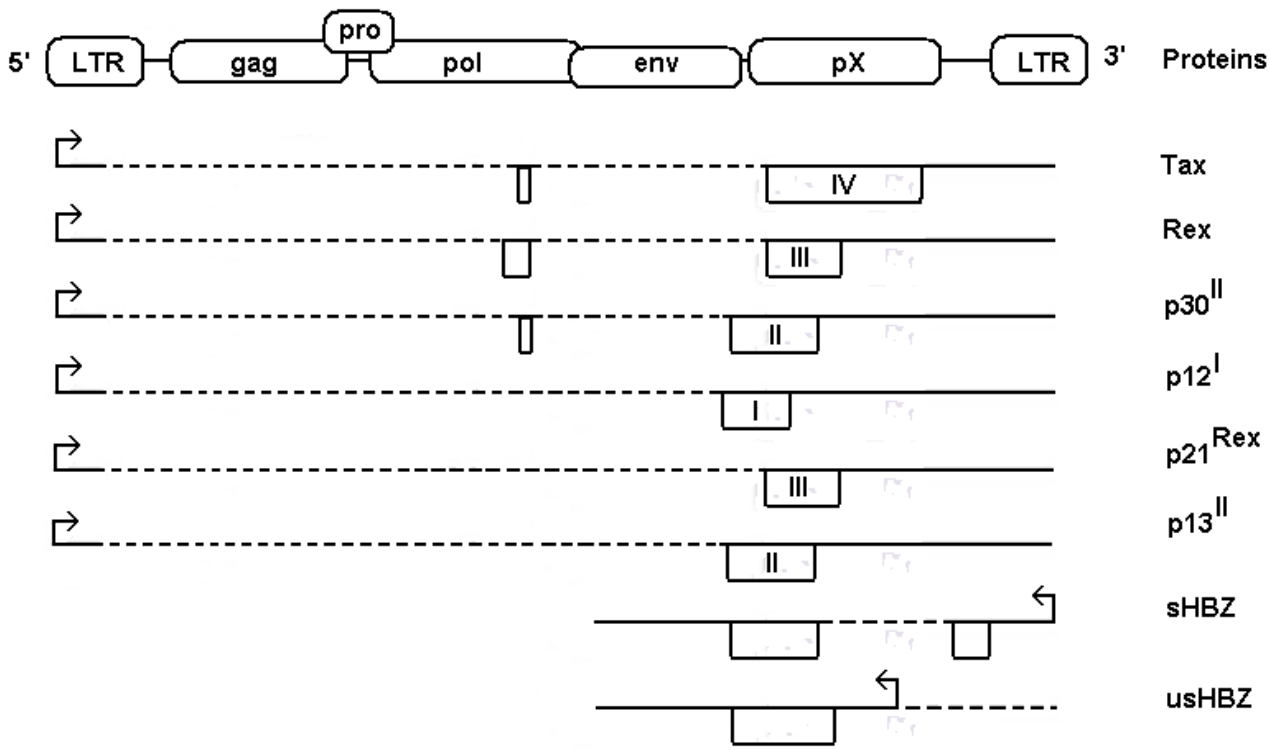

Fig. 1. HTLV-1 genomic regions, virus mRNAs and proteins. HTLV-1 encodes three classes of mRNAs from 5'-LTR: unspliced mRNA coding for gag proteins (p24, p15 and p19) and polymerases proteins (reverse transcriptase, integrase and protease); single-spliced mRNAs coding for envelope proteins (gp46 and p21), p12I, p21 Rex, p13II; and doble-spliced mRNAs coding for Tax, Rex and p30I. In addition, two isoforms of HBZ, spliced and unspliced, are encoded from the 3'-LTR on the complementary strand of the genome.

The HTLV genome is characterized by regions called gag, pol and env, flanked by two long repeated terminations (LTRs) located at the end 5' and $3^{\prime}$ containing viral promoters and 
other regulatory elements. The gag region is initially translated as a polyprotein precursor, and subsequent cleavage gives rise to mature gag proteins: the matrix protein of $19 \mathrm{kDa}$ (p19), capsid protein of $24 \mathrm{kDa}(\mathrm{p} 24)$ and nucleocapsid protein of $15 \mathrm{kDa}$ (p15). The protease is encoded by the nucleotide sequence comprising part of the $3^{\prime}$ gag region and part of the $5^{\prime}$ region of pol. Thus, the synthesis of the protease is done as part of the gag polyprotein precursor accompanied by frameshift reading. The protease is responsible for processing the gag mature products and its own cleavage to generate the mature protease molecule. The pol region encodes for two proteins, the reverse transcriptase and the integrase. The env region encodes for the viral envelope proteins. The envelope precursor protein is cleaved to give mature products, the surface glycoprotein of $46 \mathrm{kDa}$ (gp46) and transmembrane protein of $21 \mathrm{kDa}$ (p21) (Cann \& Chen, 1996). Other region, called pX, is responsible for encoding viral regulatory and acessory proteins, related to the persistence of virus infection and pathogenesis. Four ORFs (open reading frames) had been described in $\mathrm{pX}$, whose alternative splices results in sequences encoding for different proteins: p40tax, p27rex and p21rex, p12, p13 and p30 (Franchini G \& Streicher, 1995). HTLV-1 also shows transcriptional activity from the negative strand, through the $3^{\prime}$ LTR, encoding a protein known as HTLV-1 basic leucine zipper factor (HBZ) (Gaudray et al, 2002). The regulatory and acessory HTLV-1 proteins have different roles in establish a persistent virus infection and to induce HTLV-1 associated diseases.

\section{HTLV-1 life cycle}

HTLV-1 establishes a chronic infection, usually with a long period between infection and first symptoms of the diseases associated with the virus. The principal tropism is for CD4+ T cells, but also can infect other cell types such as CD8+ T cells, dendritic cells, macrophages, nerve cells, and hematologic stem cells. The life cycle (Figure 2) is characterized by the following phases (Cann \& Chen, 1996):

1. Binding of gp21/gp46 virus proteins to surface receptor on the cell membrane;

2. Fusion with membrane and penetration of viral capsid into the cell;

3. Reverse transcription of viral RNA genome into DNA by reverse transcriptase, inside the capsid;

4. Entry of viral DNA in the nucleus and its integration into the host genome, forming the provirus;

5. Synthesis of viral RNA by cellular machinery, having as template the proviral DNA, and splicing of transcripts for the formation of viral mRNAs;

6. Synthesis of viral proteins;

7. Assembly and budding of virions;

8. Proteolytic processing of capsid proteins, finally obtaining mature viral particle that is ready to infect new cells.

It is considered that during primary infection, the virus has a period of active replication by reverse transcriptase, but that the subsequent proliferation occurs mainly via clonal expansion of infected cells, or by viral sinapse, which transmit viral genome through infected cell-to-uninfected cell contact (Igakura et al., 2003). Therefore, HTLV displays low levels of intra-individual genetic variation, unlike other retroviruses. 


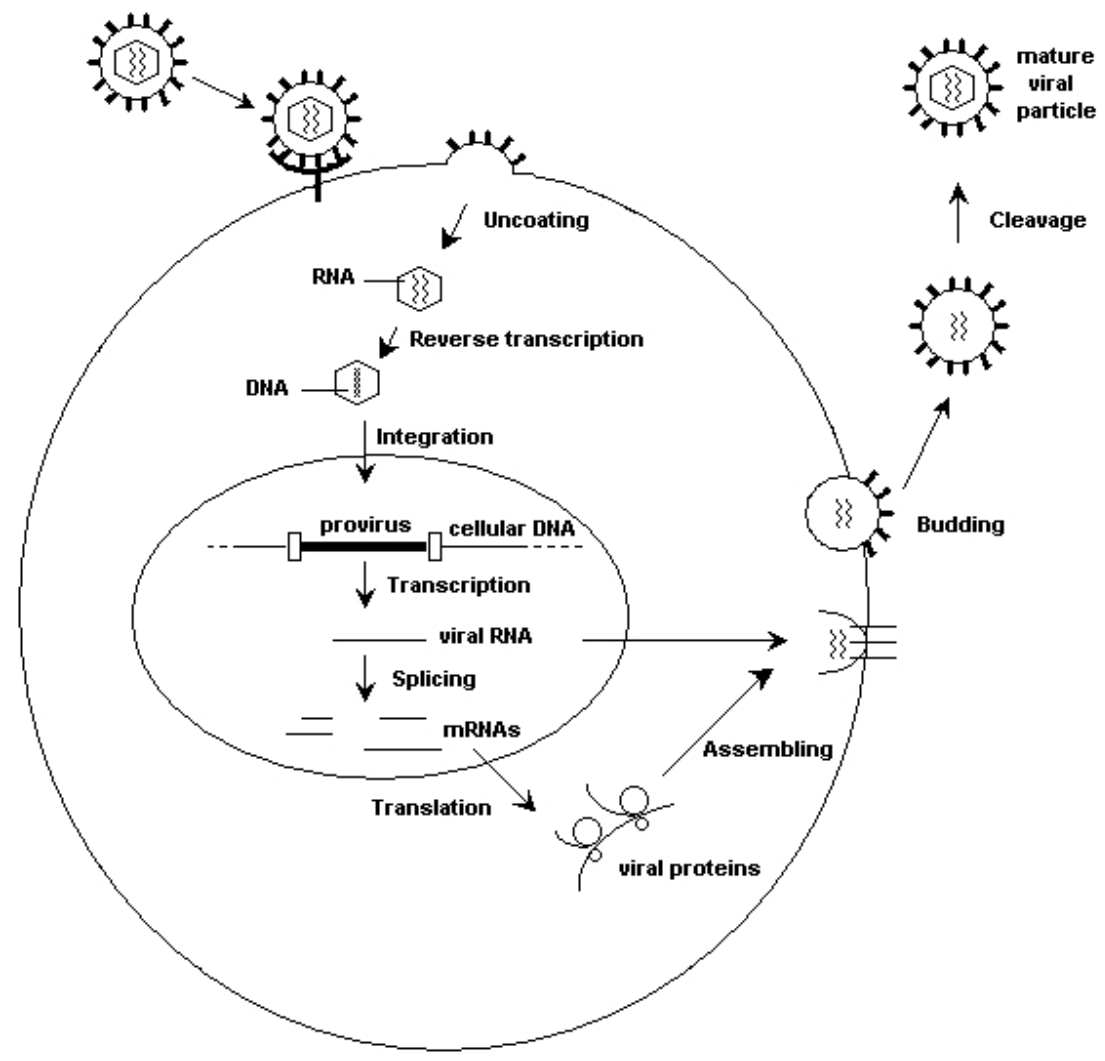

Fig. 2. HTLV life cycle. The HTLV life cycle has the following events: (1) interaction of viral envelope proteins with HTLV receptors; (2) viral particle fusion with cell membrane and uncoating of viral core; (3) reverse transcription of viral positive strand RNA into DNA; (4) integration of proviral DNA into host cellular DNA; (5) provirus transcription and splicing for formation of mRNAs; (6) translation of viral proteins; (7) virion assembly and budding of immature virions from the cellular membrane and (8) maturation of viral particle.

\section{Pathological aspects of HTLV-1 infection}

Human T-cell lymphotropic virus 1 is associated with distinct clinical entities including adult T-cell leukemia (ATL) and HTLV-1 associated myelopathy/tropical spastic paraparesis (HAM/TSP). Other inflammatory diseases such as uveitis, polymyositis, arthritis and alveolitis, as well as infective dermatitis and some types of skin lesions, are also associated with HTLV-1. HTLV-2 is not clearly associated with disease, but it has been associated with increased susceptibility to bacterial infections, with significant impact on the morbidity of carriers. Approximately $95 \%$ of HTLV-1 carriers remain asymptomatic throughout life, whereas about $5 \%$ develop diseases associated with the virus. The pathogenic potential of HTLV-1 requires that the virus diagnosis be accurate to define the virus type and to allow counsel of HTLV-1/2 carriers. 


\subsection{ATL}

HTLV-1 is able to transform cells due to ability of the viral regulatory proteins to down or up-regulate the expression of cellular genes involved in cellular proliferation and DNA repair. Tax is the major viral protein that is able to interfere in different levels, acting in the up-regulation and down-regulation of transcription factors and inhibiting the activity of cell cycle regulators and tumor suppressor proteins.

According ATL pathogenesis model, only a certain level of Tax is transiently expressed in a limited population of infected cells at a time, and in other cell populations at different times, in order to maintain a low level of this protein during viral infection. During transient expression of Tax in a given population, regardless of the immune response and destruction of some of these cells, a cell expansion can be efficiently enhanced by the multiple mechanisms of action of the Tax protein: stimulation of several genes involved in cell proliferation, induction of cell cycle phases G1 to S and S2 to M, inducing accumulation of mutations and genetic abnormalities, by attenuation of the control points of the cell cycle, DNA repair system and apoptosis. This situation would happen repeatedly over a long period in the carrier, with expansion of clones of infected cells. Finally, the clonal expansion of cell population with damaged DNA, and accumulation of new mutations by Tax activity, could lead to a process of malignant transformation of a cell clone with monoclonal expansion of the malignant clone and the onset of ATL (Yoshida, 2001 and 2010). Thus, the pleiotropic effects of Tax lead to the promotion of cell proliferation, accumulation of damaged DNA and inhibition of apoptosis of abnormal cells, thus contributing to the transformation of infected cells. Despite of all the effects of Tax protein in expanding the population of infected cells, Tax expression is detected at low levels in the carriers. This seems to be due to its immunogenicity, so that if Tax expression was continuous, the infected cell would become an easy target for the host immune response. The low expression of Tax in infected cells must be controlled by viral proteins that function as negative regulators of Tax expression, being important to evasion of immune surveillance.

Recently, HBZ has taken prominence in the pathogenesis of ATL because its negative effect on the Tax expression. It was found that HBZ is constitutively expressed in ATL cells and asymptomatic carriers, and acts as a transcriptional factor that represses the expression of viral proteins encoded by the positive strand, including Tax protein. Transcripts of tax are detected in approximately 30 to $40 \%$ of ATL patients, whereas HBZ mRNA has been detected in all studied cases of ATL. HBZ antagonizes the activation of viral transcription induced by Tax, but also promotes cell proliferation, and HBZ expression has been correlated with levels of proviral load (Satou et al., 2006). It has been suggested that HBZ, along with Rex and p30, suppresses the function of Tax, protecting infected cells from attack by cytotoxic $\mathrm{T}$ lymphocytes, thus contributing to the persistence of mutated cells clones that can continuously advance toward the phenotype of tumor cells. In this model, Tax would be important in the early stages of infection, promoting cell growth, infection from cell to cell and genetic instability of infected cells. Later, the expression of Tax cease to escape from immune surveillance. Thus, HBZ appears to has a critical role in oncogenesis triggered by HTLV-1 (Matsuoka \& Green, 2009; Yoshida, 2010).

In addition to viral proteins, host factors also play a role in determining the outcome of HTLV, such has been demonstrated by the identification of gene polymorphisms that confer susceptibility or protection to ATL, or other diseases associated with HTLV-1. 


\subsection{HAM/TSP}

HAM/TSP (HTLV-1 associated myelopathy/tropical spastic paraparesis) is an inflammatory neurodegenerative disease of a progressive feature, leading to the motor and sensory disturbance. It is characterized by atrophy of the thoracic spinal cord involving perivascular demyelination and axonal degeneration, inflammatory response in the affected region and an infiltrate of mononuclear cells, with destruction of nerve fibers in inflammatory foci leading to loss of sensory-motor ability (Izumo et al., 2000).

The main neurological features of HAM/TSP according to the WHO (World Health Organization, 1989) are: chronic spastic paraparesis that usually progresses slowly, or sometimes remains unchanged after initial progression; weakness in the lower limbs; bladder disorder that occurs earlier and constipation observed later; sexual impotence and decreased of libido; paresthesia, backache, hyperreflexia of lower limbs, often with clonus and Babinski signal; hyperreflexia of upper limbs and signals of Hoffmann and Trömner. HAM/TSP affects, in the most cases, individuals between 35-50 years old, with a predominance of females over males (2-3 times).

The low incidence of HAM/TSP (2-3\%) in HTLV-1 carriers suggests that virus-host interactions have a role in the pathogenesis of inflammatory disease. High proviral load (number of infected lymphocytes), high titers of anti-HTLV-1 antibodies in serum and cerebrospinal fluid and high levels of proinflammatory cytokines and chemokines are characteristic of patients with HAM/TSP, compared with that observed in asymptomatic carriers, suggesting that an enhanced immune response to HTLV-1 is developed in the patients (Jacobson et al., 1988; Parker et al., 1992; Yamano et al., 2002). HTLV-1 is able to cross the blood-brain barrier by migration of infected lymphocytes and, as in peripheral blood, the proliferation of infected cells within the CSF is confronted by an intense antiHTLV-1 cellular immune response in HAM/TSP patients (Cavrois et al., 2000).

Tax appears to be the main viral antigen, triggering a cytotoxic $\mathrm{T}$ lymphocytes (CTL) response. It has been suggested that the efficiency of the anti-HTLV-1 CTL response is an important determinant of HAM/TSP pathogenesis, and could explain why some HTLV-1 carriers develop a high proviral load and diseases such as HAM/TSP, whereas others remain asymptomatic. It was reported that the frequency of lysis of infected cells by CTL response were significantly associated with HAM/TSP, as well as the level os Tax expression, and both are predictors of proviral load (Asquith et al., 2005). The pathogenesis of neurological disease may be related to the ability of the infected cells in cross the blood brain barrier and to invade the central nervous system (CNS), inducing a local chronic inflammatory response promoted by anti-Tax CD8+ CTL activity, leading to high levels of proinflammatory cytokines. Thus, when the CTL response is ineffective in controlling proviral load in the CNS, an exaggerated proinflammatory state may be continuously maintained, causing the kill of the glial cells and myelopathy - the bystander damage. On the other hand, individuals presenting efficient HTLV-1-specific CD8+ cells to lyse infected cells, would eliminate high rate of infected cells, mantaining the proviral load in low level. This lytic efficiency may be related to HLA class I binding affinity to viral peptides, avidity to antigens and expression of cytolytic genes (Jeffery et al., 1999; Kattan et al., 2009; MacNamara et al., 2010; Vine et al., 2004). 
Other two hypothesis for HAM/TSP pathogenesis has been described: (1) the direct damage mechanism, which assumes that HTLV-1 infects cells residing in the central nervous system, such as astrocytes, neurons and oligodendrocytes. Infection of resident brain cells may suffer direct immune attack and excitotoxicity of neurons leading to their death; (2) the molecular mimicry, that considers that Tax cross-react with autoantigens in neurons leading to a state of autoimmunity. Neuronal proteins, such as nuclear riboproteins hnRNPA1 and hnRNP-A1B, show cross-reactivity with anti-Tax. In this mechanism, infiltrating CD8+ cytotoxic $\mathrm{T}$ cells or antibody-producing $\mathrm{B}$ cells specific for Tax may recognize self antigens, causing an autoimmune response and the incidental destruction of neurons.

Recently, it has been suggested that HBZ protein also has an important role in HAM/TSP development. At the same way as for Tax, HBZ-specific CD8+ T cell response appears to be important to maintain low proviral load and asymptomatic status of carriers (Hilburn et al., 2011).

\section{HTLV-2: Biological characteristics, pathogenesis and epidemiology}

Human T-lymphotropic virus 2 (HTLV-2) is endemic in some African populations and in Amerindians tribes from North, Central and South America, especially in Brazil, where some tribes show prevalence of 30\% (Black et al., 1996; Duenas-Barajas et al., 1992; Hjelle et al., 1993; Lairmore et al., 1990; Shindo et al., 2002). HTLV-2 is also present among intravenous drug users (IDU), mainly in the United States and in Europe (De La Fuente et al., 2006; Murphy et al., 1999). HTLV-2 shares similar epidemiological determinants with HTLV-1: presence of populational clusters with high prevalence, higher prevalence in women, increase prevalence rate with age, and the same pathways of transmission.

HTLV-2 is not known to have a precise pathologic role. It is not associated with any malignancies, but only with rare cases of subacute myelopathy like HAM/TSP, that have a more slowly progression (Araujo \& Hall, 2004). However, HTLV-2 appears to be associated with an increased incidence of pneumonia, asthma and bronchitis, bladder and kidney infection, inflammatory conditions, such as arthritis, and with increased mortality, being suggested that HTLV-2 may inhibit immunologic responses to respiratory infections and induce inflammatory or autoimmune reactions (Roucoux \& Murphy, 2004). In addition, increased incidence of sensory neuropathy has been reported in IDU infected with HTLV-2 (Dooneief et al., 1996). This association was more pronounced in patients co-infected with HIV-1, whose risk of developing peripheral neuropathy was shown to be three times higher compared with patients infected only with HIV-1 (Zehender et al., 2002). In summary, HTLV-2 has been considered less pathogenic than HTLV-1. However, studies presented around the world have been shown occurrence of illness in individuals infected only with HTLV-2 as well as co-infected with other agents, such as HTLV-1, HIV-1, HBV, HCV, Mycobacterium sp. These data confirm the importance of diagnosis, monitoring and counseling for HTLV-2.

\section{HTLV-1/2 diagnosis}

Laboratory testing for HTLV-1 and HTLV-2 infections has become routine for blood transfusion and organ transplantation in many countries worldwide. The serological tests for anti-HTLV-1/2 antibodies are divided in two major groups: the screening serological 
assays and the confirmatory tests. Some antibodies that recognize HTLV-1 antigens can either recognize those from HTLV-2, and the serological screening tests are not accurate to distinguish the both viruses' infections. Thus, confirmatory tests must diferentiate between HTLV-1 and HTLV-2.

The most used tests for the diagnosis of HTLV-1/2 are enzyme immunoassays (ELISA), indirect Immunofluorescence (IFA), Western blot (WB) and polymerase chain reaction (PCR) assays. The first one is a screening assay and the others are considered confirmatory tests. However, commercial HTLV-1/2 IFA or PCR assays are not available. "In-house" tests have been developed and used elsewhere, but this requires carefully optimization with several clinical samples to establish good patterns of sensitivity and specificity.

The HTLV serological window period is not clearly known. The period of seroconvertion is related to the route of transmission and with the level of infected cells received in this event. The virus transmission through blood transfusion is considered the most efficient route and the seroconvertion of the recipients is around two months (Manns et al., 1992), while for the other routes of transmission the seroconvertion can reach six months or more. There are no reports of infected individuals who had viral clearance.

For serological diagnosis of HTLV-1/2 is recommended one or two concomitant enzyme immunoassays with different formats and antigen composition followed by a confirmatory test in case of sample be reactive. The results of ELISA test can be: reactive, non-reactive or indeterminate (absorbance value around to cut-off). The sample is usually tested in triplicate, and if two or three replicates are reactive, a new blood collection shoul be realize and the new sample tested by ELISA. The reactivity in two or three replicates implicates in the use of a confirmatory test, such as Western Blot.

Western blot is a confirmatory assay used to test samples that were repeatedly reactives in screening tests. Commercial tests normally use as antigens viral lysate of HTLV-1, besides HTLV-1 and HTLV-2 recombinant envelope proteins. The sample will be considered seronegative if no reactivity to viral antigens is observed; indeterminate if are specific reactivity for HTLV antigens but do not fulfill the criterion of seropositivity; and seropositive if presents reactivity to all antigens defined by the manufacturer as positive pattern. Depending on the reactivity profile, WB may be not able to define the diagnosis for HTLV-1 or HTLV-2.

The high proportion of indeterminate results in the screening tests for HTLV infection has been a challenge worldwide and has been an important problem faced by blood banks. The improvement in the diagnosis for HTLV has been necessary to reduce inconclusive results and to avoid unnecessary follow-up to define the status of infection (Martins et al., 2010; Costa et al., 2011). In endemic areas, indeterminate WB results can range from $0.02 \%$ to $50 \%$. The causes of indeterminate WB tests and what is the medical importance of this status is still not clear. Molecular tests can be useful to solve the majority of these inconclusive cases, as well as to discriminate between HTLV-1 or HTLV-2 infection (Waters et al., 2011).

The techniques of molecular biology for confirmatory diagnosis of HTLV-1/2 are based primarily on the detection of viral nucleic acid in the form of proviral DNA by PCR (polymerase chain reaction). Many protocols for HTLV diagnosis by PCR has been developed in-house, with no commercial tests yet licensed. PCR for HTLV-1 and 2 has been 
particularly useful for: investigation of neonatal transmission, since the serological tests in infants can detect maternal antibodies (Ribeiro et al., 2010); discrimination between infection by type 1 or type 2 virus; definition of dual infection (HTLV-1 and HTLV-2); definition of virus subtypes; diagnostic in subjects with suspected of seroconversion; and resolution of cases with seroindeterminate results (Andrade et al., 2010, Costa et al., 2011; Waters et al., 2011). Since HTLV not presents large quantities of viral RNA circulating, the use of plasma or serum is not suitable for HTLV molecular diagnosis. Considering the HTLV tropism for lymphocytes, the biological sample of choice for the molecular diagnosis of infection is the blood. However, different biological samples containing potentially infected cells may be used for virus identification, in case of specific research studies. Currently, real-time PCR has been preferentially employed over conventional PCR because of its very higher sensitivity and specificity, low contamination risk, easeness of performance and rapidity in obtaining results, showing be viable to substitute confirmatory serological test for HTLV1/2 diagnosis (Andrade et al., 2010, Costa et al., 2011; Waters et al., 2011).

In addition of molecular tests for detection of the viral genome, molecular tests are also used to quantify the level of HTLV infectivity, or proviral load. HTLV-1 proviral load is an important risk marker for the development of diseases associated with HTLV-1. Unlike HIV, where the quantification of the burden of infection is given by the number of viral particles (quantification of viral RNA copies per mL of plasma), the load for HTLV is quantified by the number of copies of proviral DNA present in a cellular population, that mean, the measure of the number of infected cells, because there is little free HTLV-1 particle in plasma. The proviral load of HTLV-1 in peripheral blood is typically high compared with infection by other retroviruses, and although the numbers vary widely among infected individuals, the mean of proviral load in healthy carriers is significantly lower than that observed in symptomatic patients (Kamihira et al., 2003; Nagai et al., 1998; Ono et al, 1995; Yakova et al., 2005).

\section{Counseling HTLV-1/2 seropositive carriers}

The counseling to HTLV-1/2 seropositive carriers aims to clarify aspects of infection and diseases associated with the virus, to provide guidance about virus transmission pathways and treatment, besides assess the need for emotional support. It is also necessary to clarify the significance of the serological results, mainly if the individual has not been tested by a confirmatory assay or if the result has been seroindeterminate. HTLV-1/2 seroindeterminate individuals are difficult to counseling because their status as infected or not is not defined. These individuals should be informed that the result is not defined, since false-reactive results may occur, requiring additional tests (such as molecular tests) or serological monitoring to define possible seroconvertion.

Upon diagnosis of HTLV infection, it is initially recommended that the carrier be informed about the differences between HTLV and HIV, emphasizing the fact that most individuals infected with HTLV will not develop diseases, remaining asymptomatic lifelong. However, the carrier must be advised that he/she is able of transmitting the virus, and what the ways to prevent the viral transmission: to not donate blood, organs, breast milk or sperm; to not make use of shared needles, syringes or other cutting objects; to discuss with his/her partner(s) sexual about risk of virus transmission by sexual intercourse and measures to prevent it, such as condom use; to prefer cesarean delivery; and to avoid breastfeeding by 
HTLV positive mother, ensuring the nutrition of infants through natural milk from breast milk banks or artificial feeding.

It is also recommended for HTLV carriers testing for other pathogens that share the same transmission pathways, such as hepatitis B, hepatitis C and HIV. Sexual partners should be tested for HTLV, as well as all children of HTLV seropositive mothers.

In summary, counseling of infected individual is an arduous task that should involves a mutidisciplinar team, able to properly inform the carrier, take your questions and avoid hopeless attitude.

\section{Acknowledgment}

ML Martins and BH Nédir received fellowships from FAPEMIG, RG Andrade from CAPES, and EF Barbosa-Stancioli from CNPq. The studies developed by GIPH have received financial support from FAPEMIG, CNPq and Pro-Reitoria de Pesquisa da UFMG (PRPq).

\section{References}

Andrade, RG, Ribeiro, MA, Namen-Lopes, MS, Silva, SM, Basques, FV, Ribas, JG, CarneiroProietti, AB, Martins, ML. (2010) Evaluation of the use of real-time PCR for human T cell lymphotropic virus 1 and 2 as a confirmatory test in screening for blood donors. Revista da Sociedade Brasileira de Medicina Tropical, 43, pp. 111-115.

Araujo, A, Hall, WW. (2004) Human T-lymphotropic virus type II and neurological disease. Annals of Neurology, 56, pp. 10-19.

Asquith, B, Mosley, AJ, Heaps, A, Tanaka, Y, Taylor, GP, McLean, AR, Bangham, CR. (2005) Quantification of the virus-host interaction in human $\mathrm{T}$ lymphotropic virus I infection. Retrovirology, 2, pp. 75.

Black, FL, Biggar, RJ, Lal, RB, Gabbai, AA, Filho, JP. (1996) Twenty-five years of HTLV type II follow-up with a possible case of tropical spastic paraparesis in the Kayapo, a Brazilian Indian tribe. AIDS Research and Human Retroviruses, 12, pp. 1623-1627.

Cann, AJ, Chen, ISY. (1996) Human T-cell leukemia virus types I and II, In: Fields Virology 3rd edition, Fields, BN, Knipe, DM, Howley PM et al., pp. 1849-1879. Raven Publishers, Philadelphia.

Cavrois, M, Gessain, A, Gout, O, Wain-Hobson, S, Wattel, E. (2000) Common human T cell leukemia virus type 1 (HTLV-1) integration sites in cerebrospinal fluid and blood lymphocytes of patients with HTLV-1-associated myelopathy/tropical spastic paraparesis indicate that HTLV-1 crosses the blood-brain barrier via clonal HTLV1-infected cells. The Journal of Infectious Diseases, 182, pp. 1044-1050.

Costa, EA, Magri, MC, Caterino-de-Araujo, A. (2011) The best algorithm to confirm the diagnosis of HTLV-1 and HTLV-2 in at-risk individuals from São Paulo, Brazil. Journal of Virology Methods, 173, pp. 280-286.

Couroucé, AM, Pillonel, J, Lemarie, JM, Saura, C. (1998) HTLV testing in blood transfusion. Vox Sanguinis, 74, Suppl 2, pp. 165-169.

De la Fuente, L, Toro, C, Soriano, V, Brugal, MT, Vallejo, F, Barrio, G, Jiménez, V, Silva, T, Project Itínere Working Group. (2006) HTLV infection among young injection and non-injection heroin users in Spain: prevalence and correlates. Journal of Clinical Virology, 35, pp. 244-249. 
Dooneief, G, Marlink, R, Bell, K, Marder, K, Renjifo, B, Stern, Y, Mayeux, R. (1996) Neurologic consequences of HTLV-II infection in injection-drug users. Neurology, 46, pp. $1556-1560$.

Dueńas-Barajas, E, Bernal, JE, Vaught, DR, Briceño, I, Durán, C, Yanagihara, R, Gajdusek, DC. (1992) Coexistence of human T-lymphotropic virus types I and II among the Wayuu Indians from the Guajira Region of Colombia. AIDS Research and Human Retroviruses, 8, pp. 1851-1855.

Franchini, G, Streicher, H. (1995) Human T-cell leukemia virus. Baillièrés Clinical Haematology, 8, pp. 131-148.

Gaudray, G, Gachon, F, Basbous, J, Biard-Piechaczyk, M, Devaux, C, Mesnard, JM. (2002) The complementary strand of the human T-cell leukemia virus type 1 RNA genome encodes a bZIP transcription factor that down-regulates viral transcription. Journal of Virology, 76, pp. 12813-12822.

Gessain, A. (1996) Epidemiology of HTLV-I and associated diseases, In: Human T-cell lymphotropic virus I, Hollsberg P. \& Hafler DA, pp. 34-64. John Wiley and Sons, New York.

Hilburn, S, Rowan, A, Demontis, MA, Macnamara, A, Asquith, B, Bangham, CR, Taylor, GP. (2011) In vivo expression of human T-lymphotropic virus type 1 Basic LeucineZipper protein generates specific CD8+ and CD4+ T-lymphocyte responses that correlate with clinical outcome. Journal of Infection Disease, 203, pp. 529-236.

Hjelle, B, Zhu, SW, Takahashi, H, Ijichi, S, Hall, WW. (1993) Endemic human T cell leukemia virus type II infection in southwestern US Indians involves two prototype variants of virus. Journal of Infectious Diseases, 168, pp. 737-740.

Igakura, T, Stinchcombe, JC, Goon, PK, Taylor, GP, Weber, JN, Griffiths, GM, Tanaka, Y, Osame, M, Bangham, CR. (2003) Spread of HTLV-I between lymphocytes by virusinduced polarization of the cytoskeleton. Science, 299, pp. 1713-1716.

Izumo, S, Umehara, F, Osame, M. (2000) HTLV-I-associated myelopathy. Neuropathology, 20, Suppl. S65-68.

Jacobson, S, Zaninovic, V, Mora, C, Rodgers-Johnson, P, Sheremata, WA, Gibbs, CJJr, Gajdusek, C, McFarlin, DE. (1988) Immunological findings in neurological diseases associated with antibodies to HTLV-I: activated lymphocytes in tropical spastic paraparesis. Annals of Neurology, 23, Suppl. S196-200.

Jeffery, KJ, Usuku, K, Hall, SE, Matsumoto, W, Taylor, GP, Procter, J, Bunce, M, Ogg, GS, Welsh, KI, Weber, JN, Lloyd, AL,

Kalyanaraman, VS, Sarngadharan, MG, Robert-Guroff, M. (1982) A new subtype of human T-cell leukemia virus (HTLV-II) associated with a T-cell variant of hairy cell leukemia. Science, 218, pp. 571-573.

Kamihira, S, Dateki, N, Sugahara, K, Hayashi, T, Harasawa, H, Minami, S, Hirakata, Y, Yamada, Y. (2003) Significance of HTLV-1 proviral load quantification by real time PCR as a surrogate marker for HTLV-1-infected cell count. Clinical and Laboratory Haematology, 25, pp. 111-117.

Kattan, T, MacNamara, A, Rowan, AG, Nose, H, Mosley, AJ, Tanaka, Y, Taylor, GP, Asquith, B, Bangham, CR. (2009) The avidity and lytic efficiency of the CTL response to HTLV-1. Journal of Immunology, 182, pp. 5723-5729.

Lairmore, MD, Jacobson, S, Gracia, F, De, BK, Castillo, L, Larreategui, M, Roberts, BD, Levine, PH, Blattner, WA, Kaplan, JE. (1990) Isolation of human T-cell 
lymphotropic virus type 2 from Guaymi Indians in Panama. Proceedings of National Academy of Sciences U S A, 87, pp. 8840-844.

MacNamara, A, Rowan, A, Hilburn, S, Kadolsky, U, Fujiwara, H, Suemori, K, Yasukawa, M, Taylor, G, Bangham, CR, Asquith, B. (2010) HLA class I binding of HBZ determines outcome in HTLV-1 infection. PLoS Pathogens, 6, pp. e1001117.

Mahieux, R, Gessain, A. (2011) HTLV-3/STLV-3 and HTLV-4 Viruses: Discovery, Epidemiology, Serology and Molecular Aspects. Viruses, 3, pp. 1074-1090.

Manns, A, Wilks, R, Murphy, EL, Haynes, G, Figueroa, P, Barnett, M, Hanchard, B, Blattner, WA. (1992). A prospective study of transmission by transfusion of HTLV-I and risk factors associated with seroconversion. International Journal of Cancer, 51, pp. 886891.

Martins, ML, Santos, AC, Namen-Lopes, MS, Barbosa-Stancioli, EF, Utsch, DG, CarneiroProietti, AB. (2010) Long-term serological follow-up of blood donors with an HTLV-indeterminate western blot: antibody profile of seroconverters and individuals with false reactions. Journal of Medicine Virology, 82, pp. 1746-1753.

Matsuoka, M, Green, PL. (2009) The HBZ gene, a key player in HTLV-I pathogenesis. Retrovirology, 6, pp. 7.

Murphy, EL, Glynn, SA, Fridey, J, Smith, JW, Sacher, RA, Nass, CC, Ownby, HE, Wright, DJ, Nemo GJ. (1999) Increased incidence of infectious diseases during prospective follow-up of Human T-Lymphotropic Virus Type II- and I- infected blood donors. Archives of International Medicine, 159, pp. 1485-1491.

Nagai M, Usuku K, Matsumoto W, Kodama D, Takenouchi N, Moritoyo T, Hashiguchi S, Ichinose M, Bangham CR, Izumo S, Osame M. (1998) Analysis of HTLV-I proviral load in 202 HAM/TSP patients and 243 asymptomatic HTLV-I carriers: high proviral load strongly predisposes to HAM/TSP. Journal of Neurovirology, 4, pp. 586-593.

Namen-Lopes, MSS, Martins, M L, Drummond, PC, Lobato, RR, Interdisciplinary HTLV Research Group (GIPH), Carneiro-Proietti, ABF. (2009) Lookback study of HTLV-1 and 2 seropositive donors and their recipients in Belo Horizonte, Brazil. Transfusion Medicine, 19, pp. 180-188.

Ono, A, Mochizuki, M, Yamaguchi, K, Miyata, N, Watanabe, T. (1995) Increased number of circulating HTLV-1 infected cells in peripheral blood mononuclear cells of HTLV-1 uveitis patients: a quantitative polymerase chain reaction study. British Journal of Ophthalmology, 79, pp. 270-276.

Parker, CE, Daenke, S, Nightingale, S, Bangham, CR. (1992) Activated, HTLV-1-specific cytotoxic T-lymphocytes are found in healthy seropositives as well as in patients with tropical spastic paraparesis. Virology, 188, pp. 628-636.

Poiez, BJ, Ruscetti, FW, Gazdar, AF, Bunn, PA, Minna, JD, Gallo, RC. (1980) Detection and isolation of type $C$ retrovirus particles from fresh and cultured lymphocytes of a patient with cutaneous T-cell lymphoma. Proceedings of National Academy of Sciences U S A, 77, pp. 7415-7419.

Ribeiro, MA, Proietti, FA, Martins, ML, Januário, JN, Ladeira, RVP, Oliveira, MF, CarneiroProietti, ABF. (2010) Geographic distribution of human T-lymphotropic virus types 1 and 2 among mothers of newborns tested during neonatal screening, Minas Gerais, Brazil. Revista Panamerica de Salud Publica, 27, pp. 330-337. 
Roucoux, DF, Murphy, EL. (2004) The epidemiology and disease outcomes of Human TLymphotropic Virus type II. AIDS Reviews, 6, pp. 144-154.

Satou, Y, Yasunaga, J, Yoshida, M, Matsuoka, M. (2006) HTLV-I basic leucine zipper factor gene mRNA supports proliferation of adult $\mathrm{T}$ cell leukemia cells. Proceedings of National Academy of Sciences U S A, 103, pp. 720-725.

Shindo, N, Alcantara, LC, Van Dooren, S, Salemi, M, Costa, MC, Kashima, S, Covas, DT, Teva, A, Pellegrini, M, Brito, I, Vandamme, AM, Galvão-Castro, B. (2002) Human retroviruses (HIV and HTLV) in Brazilian Indians: seroepidemiological study and molecular epidemiology of HTLV type 2 isolates. AIDS Research and Human Retroviruses, 18, pp. 71-77.

Silva, EA, Otsuki, K, Leite, AC, Alamy, AH, Sá-Carvalho, D, Vicente, AC. (2002) HTLV-II infection associated with a chronic neurodegenerative disease: clinical and molecular analysis. Journal of Medicine Virology, 66, pp. 253-257.

Sullivan, MT, Williams, AE, Fang, CT, Gradinetti, T, Poiez, BJ, Enrich, GD. (1991). Transmission of human T-lymphotropic virus types I and II by blood transfusion: a retrospective study of blood components (1983 through 1988): the American Red Cross HTLV-I/II Collaborative Study Group. Archives of Internal Medicine, 151, pp. 2043-2048.

Vine, AM, Heaps, AG, Kaftantzi, L, Mosley, A, Asquith, B, Witkover, A, Thompson, G, Saito, M, Goon, PKC, Carr, L, Martinez-Murillo, F, Taylor, GP, Bangham, CRM. (2004) The Role of CTLs in Persistent Viral Infection: Cytolytic Gene Expression in CD8- Lymphocytes distinguishes between Individuals with a High or Low Proviral Load of Human T Cell Lymphotropic Virus Type 1. Journal of Immunology, 173, pp. 5121-5129.

Waters, A, Oliveira, AL, Coughlan, S, de Venecia, C, Schor, D, Leite, AC, Araújo, AQ, Hall, WW. (2011) Multiplex real-time PCR for the detection and quantitation of HTLV-1 and HTLV-2 proviral load: addressing the issue of indeterminate HTLV results. Journal of Clinical Virology, 52, pp. 38-44.

Wolfe, ND, Heneine, W, Carr, JK, Garcia, AD, Shanmugam, V, Tamoufe, U, Torimiro, JN, Prosser, AT, Lebreton, M, Mpoudi-Ngole, E, McCutchan, FE, Birx, DL, Folks, TM, Burke, DS, Switzer, WM. (2005) Emergence of unique primate T-lymphotropic viruses among central African bushmeat hunters. Proceedings of National Academy of Sciences U S A, 102, pp. 7994-7999.

World Health Organization. Report of the Scientific Group on HTLV-I and Associated Diseases, Kagoshima, Japan, December 1988: Virus diseases. Human T Lymphotropic Virus Type I, HTLV-I. (1989) Wkly Epidem. Rec., 49, pp. 382-383.

Yakova, M, Lézin, A, Dantin, F, Lagathu, G, Olindo, S, Jean-Baptiste, G, Arfi, S, Césaire, R. (2005) Increased proviral load in HTLV-1-infected patients with rheumatoid arthritis or connective tissue disease. Retrovirology, 2, pp. 4.

Yamano, Y, Nagai, M, Brennan, M, Mora, CA, Soldan, SS, Tomaru, U, Takenouchi, N, Izumo, S, Osame, M, Jacobson, S. (2002) Correlation of human T-cell lymphotropic virus type 1 (HTLV-1) mRNA with proviral DNA load, virus-specific CD8(+) T cells, and disease severity in HTLV-1-associated myelopathy (HAM/TSP). Blood, 99, pp. 88-94.

Yoshida, M. (2001) Multiple viral strategies of HTLV-1 for dysregulation of cell growth control. Annual Review of Immunology, 19, pp. 475-495. 
Yoshida, M. (2010) Molecular approach to human leukemia: Isolation and characterization of the first human retrovirus HTLV-1 and its impact on tumorigenesis in Adult Tcell Leukemia. Proceedings of the Japan Academy. Series B, Physical and Biological Sciences, 86, pp. 117-129.

Zehender, G, Colasante, C, Santambrogio, S, De Maddalena, C, Massetto, B, Cavalli, B, Jacchetti, G, Fasan, M, Adorni, F, Osio, M, Moroni, M, Galli, M. (2002) Increased risk of developing peripheral neuropathy in patients coinfected with HIV-1 and HTLV-2. Journal of Acquired Immune Deficiency Syndrome, 31, pp. 440-447. 


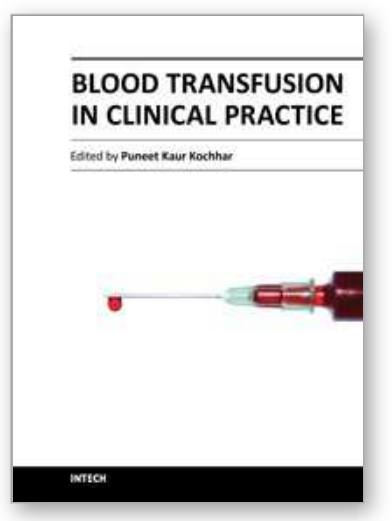

\author{
Blood Transfusion in Clinical Practice \\ Edited by Dr. Puneet Kochhar
}

ISBN 978-953-51-0343-1

Hard cover, 272 pages

Publisher InTech

Published online 16, March, 2012

Published in print edition March, 2012

Blood Transfusion in Clinical Practice focuses on the application of blood transfusion in different clinical settings. The text has been divided into five sections. The first section includes a chapter describing the basic principles of $\mathrm{ABO}$ blood group system in blood transfusion. The second section discusses the use of transfusion in various clinical settings including orthopedics, obstetrics, cardiac surgery, etc. The third section covers transfusion transmitted infections, while section four describes alternative strategies to allogenic blood transfusion. The last section speculates over immunomodulatory effects of blood transfusion.

\title{
How to reference
}

In order to correctly reference this scholarly work, feel free to copy and paste the following:

Marina Lobato Martins, Rafaela Gomes Andrade, Bernardo Hinkelmann Nédir and Edel Figueiredo BarbosaStancioli (2012). Human T-Lymphotropic Viruses (HTLV), Blood Transfusion in Clinical Practice, Dr. Puneet Kochhar (Ed.), ISBN: 978-953-51-0343-1, InTech, Available from: http://www.intechopen.com/books/bloodtransfusion-in-clinical-practice/human-t-cell-lymphotropic-viruses-htlv-

\section{INTECH}

open science | open minds

\section{InTech Europe}

University Campus STeP Ri

Slavka Krautzeka 83/A

51000 Rijeka, Croatia

Phone: +385 (51) 770447

Fax: +385 (51) 686166

www.intechopen.com

\section{InTech China}

Unit 405, Office Block, Hotel Equatorial Shanghai

No.65, Yan An Road (West), Shanghai, 200040, China

中国上海市延安西路65号上海国际贵都大饭店办公楼405单元

Phone: +86-21-62489820

Fax: +86-21-62489821 
(C) 2012 The Author(s). Licensee IntechOpen. This is an open access article distributed under the terms of the Creative Commons Attribution 3.0 License, which permits unrestricted use, distribution, and reproduction in any medium, provided the original work is properly cited. 